\title{
Comunicação
}

[Communication]

\section{Enterococcus spp. resistentes à vancomicina isolados de fezes de frangos, pombos, gamos e ratos}

[Vancomycin-resistant Enterococcus isolated from feces of poultry, pigeons, deers and rats]

\section{P. Poeta, T. Antunes, J. Rodrigues}

Universidade de Trás-os-Montes e Alto Douro, ICETA, Departamento de Higiene e Sanidade Apart. 1013, 5000-911 Vila Real, Portugal

Enterococcus é o gênero que apresenta a maior preocupação quanto à resistência aos antibióticos glicopeptídeos. Isto se deve ao incremento de sua participação em infecções oportunistas e pelo isolamento de estirpes multirresistentes nas quais a vancomicina constitui um dos poucos, senão o único, antibiótico eficaz. Na Europa, desde meados dos anos 70, o glicopeptídeo avoparcina foi utilizado como promotor de crescimento em aves e suínos. O seu consumo foi permitido na Europa e na Austrália, mas não nos Estados Unidos e Canadá. Esse antibiótico não é metabolizado quando os animais o ingerem e permanece nos intestinos de forma activa. A avoparcina é uma molécula similar à vancomicina com os mesmos mecanismos de ação e de resistência. Devido ao aparecimento de resistência cruzada entre esses antibióticos, em abril de 1997, o consumo de avoparcina foi proibido na União Européia. Nos últimos anos, diversos trabalhos, na Europa, mostraram o aparecimento de estirpes de Enterococcus resistentes à vancomicina (VRE) em amostras de diferentes origens: águas residuais, alimentos e fezes de animais saudáveis (Torres et al., 1996; Devriese et al., 1997). De fato, o uso da avoparcina como promotora de crescimento pode ter favorecido o aparecimento de estirpes VRE em animais e sua posterior disseminação ao homem, através da cadeia alimentar ou de forma direta. Os animais podem, portanto, constituir um reservatório importante de estirpes VRE (Bates et al., 1994). Apesar de existir grande especificidade de hospedeiros, as bactérias e os genes de resistência podem passar dos animais para o homem e vice-versa. Desse modo, distintos genes de resistência podem ser trocados pelos microrganismos do intestino dos animais, ser adquiridos por microrganismos saprófitas do intestino humano e, posteriormente, transferidos a possíveis patógenos, que podem ser disseminados a outros indivíduos.

Com o objetivo de verificar a presença de estirpes de Enterococcus resistentes à vancomicina, foram recolhidas com zaragatoas amostras fecais de: 25 frangos provenientes de igual número de estabelecimentos (uma por exploração) nos quais nunca se utilizou avoparcina como promotora de crescimento (F1), seis aves provenientes de diferentes explorações em que a avoparcina tinha sido utilizada até 1997 incorporada na ração (F2), oito gamos provenientes de um parque natural, 15 pombos provenientes de dois pombais e 20 ratos do campo. As amostras foram colocadas dentro de tubos com $9 \mathrm{ml}$ de solução fisiológica tamponada até chegarem ao laboratório. Após

Recebido para publicação em 17 de novembro de 2003.

Recebido para publicação, após modificações, em 13 de abril de 2004.

E-mail: ppoeta@utad.pt 
homogeneização, foram semeadas em meio de Slanetz-Bartley ${ }^{1}$ e incubadas à temperatura de $37^{\circ} \mathrm{C}$, durante $24-48$ horas. Duas colônias suspeitas de serem Enterococcus foram, posteriormente, repicadas em meio de BHI agar ${ }^{2}$ e incubadas durante 24 horas, à temperatura de $37^{\circ} \mathrm{C}$. Após coloração pelo Gram e realização da prova da catalase, foram repicadas para meio de kanamicina-esculina-azida-agar ${ }^{1}$ e incubadas à mesma temperatura, durante 24 horas. A identificação das estirpes foi feita de acordo com os caracteres fenotípicos utilizados por Facklam et al. (1989). O ensaio da sensibilidade à vancomicina foi realizado pelo método de difusão em agar ou técnica de Kirby e Bauer, utilizando discos com $30 \mu \mathrm{g} / \mathrm{ml}$ do antibiótico. Os resultados são apresentados na Tab. 1 .

As amostras de E. gallinarum isoladas de feses de galinha foram resistentes à vancomicina, independente do uso de avoparcina como promotora de crescimento. Alguns autores como Bogaard et al. (2002) isolaram VRE de frangos provenientes de explorações com histórico de uso de avoparcina, embora em menor percentagem. Apesar da avoparcina ter sido proibida em 1997, o fato de aparecerem animais com estirpes VRE pode ser explicado porque certos produtores continuam a adicionar $\mathrm{o}$ antibiótico nas rações. Por outro lado, os genes presentes nos transposons que codificam a resistência podem ser encontrados no meio ambiente e persistirem durante anos. Butaye et al. (2002), em trabalho realizado com pombos, não observaram a presença de VRE. $O$ fato de não ter sido isolado VRE em ratos impede que se façam comparações com essa espécie. O mesmo pode-se dizer sobre gamos. Não deixa, no entanto, de ser preocupante o aparecimento de VRE nessa espécie, que não tem contato direto com o homem e com a maioria dos animais domésticos. Vale lembrar que a sua carne é cada vez mais procurada. Embora realizado com pequena amostra de animais, este trabalho assinala a importância, em termos de saúde pública, que representam os animais domésticos e selvagens.

Tabela 1. Espécies de Enterococcus spp. isoladas nas amostras e sensibilidae frente à vancomicina Animais Espécie isolada Susceptibilidade à vancomicina

\begin{tabular}{|c|c|c|c|c|c|}
\hline & \multicolumn{2}{|c|}{ Resistente } & \multicolumn{2}{|c|}{ Sensível } \\
\hline & & $\mathrm{N}$ & $\%$ & $\mathrm{~N}$ & $\%$ \\
\hline \multirow[t]{3}{*}{ F1 } & E. gallinarum & 25 & $100 \%$ & 0 & $0 \%$ \\
\hline & E. raffinosus & 0 & $0 \%$ & 2 & $100 \%$ \\
\hline & E. hirae & 15 & $65 \%$ & 8 & $35 \%$ \\
\hline $\mathrm{F} 2$ & E. gallinarum & 12 & $100 \%$ & 0 & $0 \%$ \\
\hline \multirow{2}{*}{ Gamos } & E. faecium & 2 & $14,3 \%$ & 12 & $85,7 \%$ \\
\hline & E. raffinosus & 0 & $0 \%$ & 2 & $100 \%$ \\
\hline \multirow{3}{*}{ Pombos } & E. avium & 0 & $0 \%$ & 15 & $100 \%$ \\
\hline & E. faecium & 0 & $0 \%$ & 10 & $100 \%$ \\
\hline & E. faecalis & 0 & $0 \%$ & 5 & $100 \%$ \\
\hline \multirow{3}{*}{ Ratos } & E. faecium & 0 & $0 \%$ & 30 & $100 \%$ \\
\hline & E. avium & 0 & $0 \%$ & 6 & $100 \%$ \\
\hline & E. durans & 0 & $0 \%$ & 4 & $100 \%$ \\
\hline
\end{tabular}
avoparcina; F2 $=$ frangos oriundos de propriedades onde se usou avoparcina.

Palavras-chave: Enterococcus, vancomicina, avoparcina, VRE

\section{ABSTRACT}

The occurrence of vancomycin resistant enterococci (VRE) was investigated in feces of poultry, pigeons, deers and rats. Feces samples were collected from 25 broilers growing in poultry production farms that never used in the diets avaporcine as growth promoter, 6 broiler from different poultry production farms that used regularly avaporcine in the formulated diets until 1997, 8 deers from natural reservoirs, 15 pigeons, and 20 rats arrested from field conditions. The samples of Enterococcus gallinarum isolated from poultry feces were resistant to vancomycin independently of the use of avaporcine in the formulated diet.

Keywords: Enterococcus, vancomycin, avoparcin, VRE

${ }^{1}$ Merck

${ }^{2}$ Difco 


\section{REFERÊNCIAS BIBLIOGRÁFICAS}

BATES, E.M.; JORDENS, J.Z.; GRIFFITS, D.T. Farm animals as a putative reservoir for vancomycin resistant enterococcal infections in man. J. Antimicrobiol. Chemother., v.34, p.507516, 1994.

BOOGAARD, A.E.; WILLEMS, R.; LONDON, $\mathrm{N}$. et al. Antibiotic resistance of faecal enterococci in poultry, poultry farmers and poultry slaughters. Antimicrobiol. Agents Chemother., v.49, p.497-505, 2002.

BUTAYE, P.; BAELE, M.; DEVRIESE, L.A. et al. Comparison of susceptibility to antimicrobials of the enterococcal species isolated from pigeons (Columbia vivia). Microbiol. Drug Resist., v.3, p.215-218, 2002.
DEVRIESE, L.A.; LAURIER, L.; De HERDT, P. et al. Enterococcal and streptococcal species isolated from faeces of calves, young cattle and diary cows. J. Appl. Bacteriol., v.72, p.29-31, 1992.

FACKLAM, R.R.; COLLINS, M.D. Identification of Enterococcus species isolated form human infections by a conventional test scheme. J. Clin. Microbiol., v.27, p.731-734, 1989.

TORRES, C.; TENÓRIO, M.; ZARAZAGA, M. et al. Impacto medioambiental del consumo de antibióticos en el desarrollo de mecanismos de resistência. Zubía, n.8, p.275-286, 1996. 